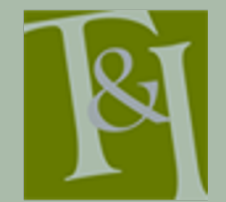

The International Journal for Translation \& Interpreting Research trans-int.org

\section{Market demand for conference interpreting in South Korea: Sifting through the signals}

\author{
Jiun Huh \\ Ewha Womans University, Republic of Korea \\ huhjiun@ewha.ac.kr
}

DOI: 10.12807/ti.113201.2021.a05

\begin{abstract}
This paper explores the market demand for conference interpreting in South Korea by examining the signals that users perceive as important for professional conference interpreting services. The findings are based on a questionnaire-based survey of 109 participants who have experience using conference interpreting services. The results indicate that quality of interpreting, domain-specific interpreting experience, and certification of interpreting competence are important signals, suggesting that users are aware of the importance of quality. However, academic degrees in interpreting are found to have relatively weaker signaling power, suggesting the presence of information asymmetry-meaning users have less information about interpreters' qualifications than suppliers do. The findings are discussed in relation to users' price perceptions. The paper also addresses the service aspect of conference interpreting, shedding light on the "interpreting as a service" approach, based on an end-to-end service concept in both training and practice. The findings suggest future directions both in terms of market development and interpreter training.
\end{abstract}

Keywords: market demand; signaling; signals; conference interpreting; interpreting quality; certification

\section{Introduction}

Conference interpreting serves the market demand for multilingual communication. The market demand often determines the skillsets and qualities required for the job and also affects the perception of an interpreter's status. Interpreters have been known to have access to high profile people and privileged places, enjoy a high level of remuneration, and perform extremely difficult and intellectual tasks (Jones, 2002, p. 128; Pöchhacker, 2011, p. 322; Setton, 2010). However, Dam and Zethsen (2013) reveal a different perspective, based on a survey they conducted. Dam and Zethsen (2013) found that, although interpreters are satisfied with their salaries and the high level of expertise required for their jobs, they believe that their occupational prestige depends on the assessments of people from outside the profession such as clients and the 
general public, who, unfortunately, often present negative views on the importance of the interpreting profession.

There may be a range of reasons for these negative perceptions, but some might derive from unfavorable experiences users may have had with interpreting services provided by unqualified interpreters. Negative perceptions of the profession are problematic because they may lead to lower levels of expectation which in turn may result in lower-quality service. Clients who are unfamiliar with interpreter services lack awareness of appropriate selection criteria due to their inexperience with interpreting tasks and the working process (Mikkelson, 2009). Furthermore, not all markets have interpreter certification systems that provide standard selection criteria that are readily available to users. While conference interpretation is highly competitive due to clients being highly selective, this may be confined to cases where clients, accustomed to working with interpreters, require a demonstration of competence, such as membership of associations for professional interpreters and an academic degree in interpreting and translation (Mikkelson, 2009). Clients' inability to select quality interpreters makes it possible for interpreters without formal interpreter training to enter the market, thereby producing a vicious cycle of low pay, low status, and fewer incentives for interpreters to invest in building competence (Pérez-González \& Susam-Saraeva, 2012).

Against this backdrop, this paper aims to explore the market demand for conference interpreters in South Korea. The paper focuses on the key elements that users perceive as important for professional conference interpreting services in the South Korean context. These key elements are examined based on the concept of 'signaling mechanisms,' in which overall signals are explored encompassing not only interpreting quality but also credentials, work experience, business approach, ethics, and Public Relations (PR). The researcher conducted a survey among interpreting service users and asked them about the signals they would consider important when looking for professional interpreting services. The results of the survey were analyzed to examine their understanding of the interpreting service, the criteria they would adopt in their choice of interpreters or interpreting services, and what they would expect from professional conference interpreting services. The findings are expected to provide an insight into current users' demands, in terms of interpreter qualifications, and to propose future directions for serving market needs in the South Korean context. The paper is organized as follows. I will review the literature on signaling mechanisms in the job market, before relating these to the various aspects of interpreting. Next, I will introduce the design of the survey on signaling, before describing survey findings in more detail, and analyzing these further in section 5. I will then present my concluding remarks and suggestions for future directions.

\section{Literature review}

\subsection{Signaling mechanisms}

In the job market, employers do not have a complete understanding of an individual's productive capabilities at the time of hire, which makes hiring an 
investment decision (Spence, 1973, p. 356). Employers often make decisions without certainty, which is akin to buying a lottery ticket (Spence, 1973, p. 356). To minimize the uncertainty factor, employers need reliable information that credibly convinces them of a job candidate's qualifications, such as an academic degree or occupational certification. Economic theory refers to this information as a "signal", which is a message denoting credible information about a worker's competence, productivity, or quality (Chan, 2009, p. 156).

In contrast with employing an individual over a more extended period, hiring a conference interpreter for a one-off event can be considered a highstakes investment decision because the limited timeframe will not allow for the correction of bad selection decisions. In this case, the signaling power of the interpreter's qualifications becomes very important. When hiring a freelance conference interpreter for an event, clients may be interested in the overall productivity of the interpreter (Han, 2013, pp. 77-87; Viaggio, 2016). Interpreting quality would be the most crucial element, but other elements might also be considered if we take into account that interpreting involves pre-process, peri-process, in-process, and post-process activities (Kalina, 2005). Signals of interpreters' productivity may therefore include, but not be limited to, their educational background, job experience, and certification. For the purpose of the present research, signals for professional conference interpreting services or simply "signals" can be defined as information that users perceive will convey critical information about the professional interpreting service that they may expect from conference interpreters. In the sections that follow, I will discuss the various signals for professional conference interpreting services that require attention to understand the market demand for conference interpreting.

\subsection{Signals and credentials for conference interpreting}

In South Korea, notwithstanding the presence of a total of 12 graduate interpreting programs, an influx of untrained semi-professionals with bilingual capabilities, added to the absence of a conference interpreting certification system, is creating market disorder, where end-users find it challenging to identify the right signals to distinguish qualified interpreters from unqualified ones (see Huh, 2016; Park, 2010; Park, 2019) ${ }^{1}$. Research into the translation market presents a similar impression, albeit in markets outside of Korea. In Chan's (2009) research on the translation signaling framework, an academic degree was perceived as a more reliable signal than job experience and certification. Certification in Chan's (2009) survey is unfortunately regarded only as add-on information due to a misunderstanding of the professional translation certification systems. I would argue that the under-functioning signaling mechanism is giving rise to new commercial platforms such as Proz.com, where professional experience is more valued than academic credentials (Pym, Orrego-Carmona \& Torres-Simón, 2016). The Proz.com

\footnotetext{
${ }^{1}$ Clients also resort to their in-house bilingual staff. Interpreters with no professional training background or "self-made interpreters" often take on interpreting and translation tasks in-house because clients believe that these tasks only require subject knowledge and bilingual capabilities (Kwak, 2004; Park, 2016).
} 
platform even established its own certification system - the Certified PRO Network - where certification is awarded based on translation quality, business reliability, industry credentials, peer revision, professional training in translation, and translation experience (Pym et al., 2016).

For professional conference interpreting jobs, clients set high standards and require candidates to demonstrate their interpreting competence through exams or membership of professional interpreter associations, which helps the profession maintain its high status, at least in some markets (Mikkelson, 2009). Unfortunately, the realities in the broader market may not always work to the benefit of qualified professional interpreters. Lacking knowledge of the profession, such as interpreting mechanisms and qualifications for competence, naïve users might select unqualified interpreters because they prioritize the wrong signals (Chan, 2009; Mikkelson, 2009). User knowledge, perception, and appreciation of the profession are important when it comes to selecting a conference interpreter.

In that regard, the issue of signaling is related to the professionalization of interpreting as well, because it denotes the process of an occupation reaching the highest levels of competence and integrity (Jewell, 2014). Professionalization of a profession can be assessed based on a set of traits, such as credentials, a code of ethics, salary, continuing professional development, and culture (Witter-Merithew \& Johnson, 2004), or occupational status indicators, such as remuneration, education, expertise, visibility, power or influence, and value to society (Dam \& Zethsen, 2013). The more professionalized a profession, the more reliable the signals for qualifications and the fewer variations between standards. Reliable signals facilitate users' selection process and help filter out unqualified practitioners.

\subsection{Signals and interpreting quality}

As clients recruit interpreters, one the most important considerations aside from credentials would be around the crux of the interpreting service: the quality of interpreting. In this context it is useful to discuss users' quality expectations here. Building on Bühler's (1986) study on the evaluation of conference interpretation and interpreters where the author assumed user expectations from interpreters' responses, Kurz (1993) employs eight of Bühler's criteria when she surveyed interpreting service users to test Bühler's hypothesis. Of the eight criteria, content items, such as logical cohesion, sense consistency, and correct terminology are perceived as important by users, while fluency, completeness, grammar, voice, and accent are considered less important. Other researchers came to similar conclusions. Marrone's (1993) case study found that users focused more on information completeness and fidelity than prosodic or linguistic features. Kopczynski's (1994) survey on users also revealed that content was preferred over form, and content and terminology were the two most important features for them. Moser (1996) reported that listeners overwhelmingly expressed a preference for faithfulness to the original, while clarity of expression and terminology were also considered important criteria. The aforementioned user survey results favoring content items present an interesting comparison with interpreters' criteria as presented in Bühler's (1986) study, which tend to underline the importance of both content and form. 
In this paper, I think it is worthwhile to explore whether the criteria preferred by users in the previous studies also serve as important signals for conference interpreting service users in South Korea.

\subsection{Signals and interpreting as a service}

Having focused on the core element of interpreting performance, I will now view interpreting from a wider perspective. Interpreting is basically a "service" delivered using an interpreter's skills and expertise. A service can be characterized by its intangibility, simultaneity, inconsistency, and perishability (Lovelock \& Gummesson, 2004; Shostack, 1977). A service is provided by people, which makes it difficult to maintain consistent quality, especially during peak demand, and furthermore, service quality cannot be assured through measuring, testing, or verifying ahead of delivery, and evaluation of quality tends to be subjective (Du Tertre, 1999, pp. 24-27; Hirschman, 1980; Lin, 2015; Zeithaml, Parasuraman \& Berry, 1985, pp. 33-35).

Consumers perceive that the quality of an interaction, the service delivery process, and physical environment play important roles in addition to the quality of an output (Dagger \& Sweeney, 2007; Lee, 2014, p. 97; Ryu, Lee \& Gon Kim, 2012; Shostack, 1977). In that regard, looking at the interpreting industry through a service-oriented lens, instead of focusing on interpreting output alone, might bring added value. If interpreting is understood as a service, business and market values have to be created to satisfy both parties in the exchange, which will require considering elements such as supply and demand, quality, credentialing, and training (Eser, 2020). In interpreting, a service-based approach can encompass the interpreting process end-to-end, from searching for providers, comparing with alternatives, receiving consultation, and purchasing, to after-purchase actions such as handling feedback. In taking a service-based approach, the abstract nature of a service should be taken into account. Doing so makes it important to focus on the tangible evidence and integrate this into service realities to positively impact the service perception, instead of marketing an already abstract concept with abstract associations (Shostack, 1977, p. 78). In the case of the interpreting services, examples of tangible evidence may include (i) environment as evidence, such as forms used for quotations and invoicing, (ii) media as evidence, such as websites and social media platforms, and (iii) people as evidence, such as a profile or packaging of the person providing the service. Based on Kalina's (2005, pp. 779-781) parameters for quality assurance, it would be worthwhile to explore preprocessing steps related to environment as evidence - such as, inquiry, advisory, and quotation - and media as evidence.

Media as evidence, such as promotion and marketing efforts for interpreting, deserves particular attention as online and social media has recently been increasingly integrated into the marketing strategies of many businesses recently in an attempt to raise brand trust, affect, and loyalty (Orzan, 2016). Influencer marketing is riding on the trend, with popular personalities shaping attitudes of consumers through their postings and interactions on social media channels (Freberg, Graham, McGaughey \& Freberg, 2011). This may be well-aligned with service businesses, where consumers tend to rely on word-ofmouth referrals from private sources or independent organizations due to the 
intangible and inconsistent nature of service (Bansal \& Voyer, 2000; Berry, 1980; Zeithaml et al., 1985). However, credibility remains a thorny issue. Porter, Anderson \& Nhotsavang (2015) report low confidence levels of senior managers on social media content. Moreover, for individual professionals, in particular, credibility can be raised when social media content is presented from indirect sources such as organizations or news media outlets rather than from the individual directly (Na, Kunkel \& Doyle, 2020). With these views in mind, it would help to explore the views of users on what counts as an effective public relations (PR) and interpreter sourcing method.

\subsection{Price signals}

Price is another critical factor in the service industry. When consumers associate price with quality, it is because they are left with very little information on the outcome of the service (Ding, Ross \& Rao, 2010; Lambert, 1972; Rao \& Monroe, 1988; Stiglitz, 1987). Consumers with little interpreting service experience may suffer from severe information asymmetry, where interpreters hold more information with regards to expected interpreting quality and interpreter qualifications than service users. This may lead to adverse selection, with consumers ending up purchasing low quality interpreting services. With repeated events of adverse selection, consumers may begin to make pricequality associations to avoid adverse selection (Lee, 2014).

The amount users are prepared to pay, however, would be influenced by a reference price, which is defined as a standard price which buyers compare other prices against (Monroe, 1973). The reference price offers a glimpse into users' perception of the value of the interpreting service, which may also denote the status of interpreting as an occupation. The reference price has an anchoring effect that serves as a point of departure for any price negotiations in the future (Kahneman \& Tversky, 1979; Tversky \& Kahneman, 1974). The reference price is divided into an external reference price, informed by the standard price or the competition's price, and an internal price, which is based on personal sources or experience (Mazumdar \& Papatla, 2000). Whether consumers perceive an offered price as expensive or not is usually determined based on the external reference price (Biswas, Pullig, Krishnan \& Burton, 1999; Kopalle \& Lindsey-Mullikin, 2003). In this paper, I will explore how users perceive the external reference price of interpreting services to see how users' perceived value of interpreting services translates to the acceptable price range that they are willing to pay.

\subsection{Signals and aesthetic quality}

As discussed in the previous sections, conference interpreting is a highly intellectual activity requiring language proficiency, subject matter knowledge, multitasking, memory, analysis, and judgment, to name a few. However, in recent years, self-made, semi-professionals without an interpreter training background have entered the market in South Korea (Park, 2010; Park, 2019). These self-made interpreters are, in some cases, better known than qualified conference interpreters, due to the celebrity status of the formers (Huh, 2016; Park, 2019). This is also related to the rise of "good-looking interpreters," as reported by Cho (2017). With an oversupply of interpreters in the market, 
personal aesthetics have emerged as an alternative method to add value (Cho, 2017, pp. 151-153). In addition, in a gendered employment structure, where clients are predominantly male and interpreters are mainly female, ageism concerns are raised as younger interpreters are perceived to be favored (Cho, 2017, pp. 159-161). The trend can be explained using the concept of "aesthetic labor" which is presented by Warhurst, Nickson, Witz, and Cullen (2000) and denotes employers' efforts to transform workers' aesthetically geared competencies through recruitment and training. This trend is observed in many other fields, including the hospitality and media industries. In Cho's (2017) research, interpreters describing how they engage in aesthetic labor to deliver a "perfect package," complain that the prioritization of aesthetics devalues the fundamental professional qualities of interpreters (Cho, 2017, p. 157). Also, with the recent rise of social media as a PR and marketing platform, some interpreters are using these platforms to share their interpreting activities and enhance their visibility. The visual focus of these platforms has the potential of reinforcing the trend towards aesthetic qualities. Although the trend presents concerns, considering Cho's (2017) interviewee profile - which consists only of interpreters - and the dearth of research in this area, it would be worthwhile to listen to users' opinions, which I will present and discuss in the following sections.

\section{Study method}

\subsection{Study design}

In order to explore the signals for professional conference interpreting services, I conducted a questionnaire-based survey involving participants who had used professional interpreting services. The questionnaire covered potential signals based on previous studies on signaling, interpreting quality, interpreter status, professionalization, service industry, social media, and aesthetics qualities, which I discussed in the literature section. Table 1 below presents information on the design of the questionnaire. The same set of questions about potential signals was asked for both simultaneous interpreting and consecutive interpreting to allow for comparisons between the two different interpreting modes. The questionnaire included (i) thirty-two closed-ended questions, (ii) one open-ended question, and (iii) ten questions on basic demographic information. Most of the closed-ended questions used a five-point scale, with 1 indicating "strongly disagree" and 5 indicating "strongly agree" (See English translation of the questionnaire in Appendix).

\subsection{Procedure}

The author designed the questionnaire and outsourced the implementation of the survey to Macromill Embrain, an online market research company in South Korea. The survey was conducted between February 15 and February 19, 2019. The invitation to the survey with a weblink was sent out to 11,150 potential respondents, and a total of 109 participants completed the survey. All participants were 20 years or older, employed or self-employed, had at least 1 year's work experience, and had experienced conference interpreting service in 
their work in the previous 5 years, resulting in a response rate of $0.98 \%$. Interpreters and students were screened out to specifically target users of interpreting services. The author analyzed the data using IBM SPSS Statistics 25 . The survey was carried out in Korean and the excerpts were translated into English by the author.

Table 1: Questionnaire design

\begin{tabular}{|c|c|c|}
\hline $\begin{array}{l}\text { Category } \\
\text { (No. of } \\
\text { questions) }\end{array}$ & Items & Response type \\
\hline \multirow[t]{2}{*}{ Signals (26) } & $\begin{array}{l}\text { - Credentials (academic degree, certification) } \\
\text { - Professional experience (general, domain- } \\
\text { specific, organization-specific, high-profile) } \\
\text { - Quality (content accuracy, completeness, } \\
\text { fluency, terminology, grammar, } \\
\text { pronunciation) } \\
\text { - Sourcing method (personal source, agency } \\
\text { recommendation) } \\
\text { - Ethics } \\
\text { - Professional conduct } \\
\text { - Interpreting as a business service (fast } \\
\text { response to inquiries, systematic quotation a } \\
\text { nd invoicing, communication of service } \\
\text { details, customer-friendly attitude, speedy } \\
\text { recruitment process) } \\
\text { - Promotion (website, social media) } \\
\text { - Others (appearance, celebrity interpreter) }\end{array}$ & Five-point scale \\
\hline & - Age & Multiple choice \\
\hline $\begin{array}{l}\text { Potential } \\
\text { needs (1) }\end{array}$ & - Assessment of interpreting service needs & Multiple choice \\
\hline $\begin{array}{l}\text { Certification } \\
\text { (3) }\end{array}$ & - Certification requirements & Multiple choice \\
\hline Price (2) & $\begin{array}{l}\text { - Preferred price for simultaneous interpreting } \\
\text { and consecutive interpreting service }\end{array}$ & Sliding scale \\
\hline \multicolumn{2}{|c|}{ Demographics (10) } & Multiple choice \\
\hline \multicolumn{2}{|c|}{ Comments (1) } & Open-ended \\
\hline
\end{tabular}

\subsection{Participants}

A total of 109 participants responded to the survey. The profile of the participants was fairly evenly distributed in terms of gender, age, work experience, job title, organization size, and sector. The summary of the participant demographic data is presented in Table 2. 
Table 2: Participant data

\begin{tabular}{|l|l|l|l|}
\hline Item & Breakdown & $\mathrm{N}$ & $\%$ \\
\hline Age & $20-29$ & 26 & $23.9 \%$ \\
& $30-39$ & 39 & $35.8 \%$ \\
& $40-49$ & 44 & $40.4 \%$ \\
\hline Gender & Female & 49 & $45.0 \%$ \\
& Male & 60 & $55.1 \%$ \\
\hline Employment by & Government, public sector & 13 & $11.9 \%$ \\
sector & ICT, game & 12 & $11.0 \%$ \\
& Manufacturing, logistics, sales & 23 & $21.1 \%$ \\
& Accounting, business, finance, Law & 11 & $10.1 \%$ \\
& Media and entertainment & 3 & $2.8 \%$ \\
& Construction, architecture, civil & 10 & $9.2 \%$ \\
& engineering & 10 & $9.2 \%$ \\
& Healthcare & 9 & $8.3 \%$ \\
& Research \& Education & 18 & $16.5 \%$ \\
\hline Work experience & $1-5 y$ & 32 & $29.4 \%$ \\
& $6-10 y$ & 35 & $32.1 \%$ \\
& $11-15 y$ & 19 & $17.4 \%$ \\
& $\geq 16 y$ & 23 & $21.1 \%$ \\
\hline Position & Staff & 22 & $20.2 \%$ \\
& Assistant Mgr. & 31 & $28.4 \%$ \\
& Section Chief & 26 & $23.9 \%$ \\
& Department Head & 19 & $17.4 \%$ \\
& Executive & 4 & $3.7 \%$ \\
& CEO & 5 & $4.6 \%$ \\
& Others & 2 & $1.8 \%$ \\
\hline Number of & $<30$ & 32 & $29.4 \%$ \\
& $\geq 30,<100$ & 27 & $24.8 \%$ \\
& $\geq 100$ & 50 & $45.9 \%$ \\
\hline Total & & 109 & $100 \%$ \\
\hline
\end{tabular}

\section{Data Analysis}

This section presents an overview of the survey data. While no significant difference was found between participants' perceptions of potential signals between simultaneous interpreting (hereafter, "SI") and consecutive interpreting (hereafter, "CI"), the overall results based on signal items and participants' demographic data presented an interesting landscape. I will discuss the results in more detail in Section 5.

\subsection{Educational background}

Generally, the career path towards becoming a professional conference interpreter in South Korea entails completing a training program at a graduate school of interpreting and translation. Even so, when asked whether interpreters need to possess a Master's degree in interpreting, the average ratings stood only at $3.1560(\mathrm{SD}=1.0468)$ for $\mathrm{SI}$ and 3.1468 for $\mathrm{CI}(\mathrm{SD}=0.9509)$, respectivelyindicating that participants did not set a particularly high value on an academic specialty background in interpreting. 


\subsection{Certification}

The survey asked if participants would like to request certificates in professional interpreting to ensure an interpreter's competency. The responses were positive, with a mean score of $3.7156(\mathrm{SD}=0.8508)$ for $\mathrm{SI}$ and 3.6147 for $\mathrm{CI}(\mathrm{SD}=$ 0.8267), which shows that participants put more value on certification of interpreting competency than academic background.

When asked whether an official certification system should be put in place, most of the participants $(n=100,91.7 \%)$ responded favorably. The breakdown for their preferred type of certification system is shown in Table 3:

Table 3: Preferred types of certification (Single select multiple choice)

\begin{tabular}{|l|l|l|l|}
\hline Necessity & Breakdown & $\mathrm{N}$ & $\%$ \\
\hline Necessary & $\begin{array}{l}\text { Certification issued by representative } \\
\text { interpreter association }\end{array}$ & 42 & $38.5 \%$ \\
\cline { 2 - 4 } & National Certification & 25 & $22.9 \%$ \\
\hline & $\begin{array}{l}\text { Domain-specific certification issued by relevant } \\
\text { government agency/public agency }\end{array}$ & 23 & $21.1 \%$ \\
\cline { 2 - 4 } & Certification from commercial organizations & 10 & $9.2 \%$ \\
\cline { 2 - 4 } & Subtotal & 100 & $91.7 \%$ \\
\hline Not necessary & 9 & $8.3 \%$ \\
\hline Total & 109 & $100 \%$ \\
\hline
\end{tabular}

The most preferred type of certification was one overseen by a representative interpreter association. A certification system established by commercial organizations was the least preferred one. Nine participants responded that a certification system was not necessary. The reasons for the negative opinions were as follows: Five out of the nine respondents said that they could not place their trust in the validity of any certification; three out of the nine respondents said a master's degree in interpreting was enough to prove interpreting competence; and another three responded that, unless all interpreters joined the system, the certification system would not gain traction. Comments from the open-ended question underlined the importance of the validity and reliability of a certification system. Excerpts from the comments are presented below:

I could trust the quality of all interpreting services if there was a widely recognized organization that proves and guarantees interpreting quality. (Participant 67)

We need a reliable system that can distinguish and verify quality interpreters. (Participant 80)

\subsection{Interpreting experience}

Participants placed high importance on interpreting experience and, in particular, on interpreting experience in subject areas related to their field, i.e., domain-specific interpreting experiences (see Table 4). While domain-specific interpreting experience, general interpreting experience, and organizationspecific interpreting experience were perceived as important for both SI and CI, having experience in high profile conferences was not valued highly, scoring only a mean of 3.3303 for both SI and CI. 
Table 4: Interpreting experience

\begin{tabular}{|l|c|c|}
\hline \multicolumn{1}{|c|}{ Item } & SI & Cl \\
& Avg. (S.D.) & Avg. (S.D.) \\
\hline General & $3.9541(0.7744)$ & $3.8807(0.7419)$ \\
\hline Domain-specific & $4.1743(0.8372)$ & $4.1560(0.6828)$ \\
\hline Organization-specific & $3.7156(0.8933)$ & $3.7706(0.7892)$ \\
\hline High profile & $3.3303(0.8395)$ & $3.3303(0.7941)$ \\
\hline
\end{tabular}

The importance of a domain-specific interpreting experience was stressed further in participants' comments. Many underlined the importance of interpreting terminology accurately and having relevant subject knowledge. Excerpts from the comments from the open-ended questions are presented below:

Some young interpreters seem to have a misconception that interpreting is only about having good language skills. Yet, good interpreting entails not only language competence but also domain-specific knowledge or cultural understanding. I hope interpreters gain basic domain knowledge when they do their work. (Participant 6)

We need more interpreters with specialized knowledge. There are some cases when interpreters interpret terminology inaccurately. (Participant 8)

Interpreting faithfully is important. But we also need interpreters who study and understand the business objective, topic knowledge, and business contexts of a given situation. (Participant 17)

The perceived importance of interpreting experience was more pronounced among groups with longer work experience. The Kruskal-Wallis test revealed that respondents with more than 16 years of work experience placed more importance on general interpreting experience, particularly when compared to the least experienced group (see Table 5).

Table 5: Importance of interpreting experience by respondents' work experience

\begin{tabular}{|l|c|c|}
\hline \multirow{2}{*}{ Item } & \multicolumn{2}{|c|}{$\begin{array}{c}\text { Work experience } \\
\text { Avg. (S.D.) }\end{array}$} \\
\cline { 2 - 3 } & $1-5 \mathrm{y}$ & $16 \mathrm{y}+$ \\
\hline $\begin{array}{l}\text { General interpreting } \\
\text { experience (SI) }\end{array}$ & \multicolumn{1}{|c|}{$3.6563(.9020)$} & $4.3043(.6350)$ \\
\cline { 2 - 3 } & $\begin{array}{l}\text { Significant difference: } \chi 2=8.82, p=.032, \mathrm{df}=3 \\
\text { Pairwise comparison: } 16 \mathrm{y}+>1-5 \mathrm{y}(\mathrm{p}=.018)\end{array}$ \\
\hline
\end{tabular}

\subsection{Interpreting quality}

Interpreting quality was perceived as a very important signal by participants. For both SI and CI, mean scores for content accuracy, completeness, and terminology were all very high (see Table 6), and the correlations between these three variables were also high (see Table 7). Mean scores for linguistic qualities such as fluency, grammar, and pronunciation were also high but below the ratings for content accuracy, completeness, and terminology. This indicates that 
participants most valued the interpreting qualities of accurate and complete delivery of meaning and terminology.

Table 6: Interpreting quality

\begin{tabular}{|c|c|c|}
\hline Item & SI & Cl \\
& Avg. (S.D.) & Avg. (S.D.) \\
\hline Content Accuracy & $4.4862(.6179)$ & $4.4128(.7723)$ \\
\hline Terminology & $4.4771(.7277)$ & $4.4128(.7480)$ \\
\hline Completeness & $4.4037(.7087)$ & $4.4128(.7228)$ \\
\hline Fluency & $4.1376(.7132)$ & $4.0000(.8165)$ \\
\hline Grammar & $3.7156(.8061)$ & $3.8991(.8159)$ \\
\hline Pronunciation & $3.6881(.7900)$ & $3.8716(.7341)$ \\
\hline
\end{tabular}

Table 7 lists significantly correlated item pairs related to quality. Interestingly, "content accuracy" and "celebrity interpreter" were negatively correlated, suggesting that the more participants valued quality, the less they were interested in whether an interpreter was widely known either through mainstream media or a social media presence.

Table 7: Highly correlated quality item pairs

\begin{tabular}{|c|c|}
\hline Item pair & Correlation coefficient \\
\hline Terminology $(\mathrm{SI})$-Completeness $(\mathrm{Cl})$ & $.643(\mathrm{p}<0.01)$ \\
\hline Completeness $(\mathrm{SI})$-Content Accuracy $(\mathrm{Cl})$ & $.606(\mathrm{p}<0.01)$ \\
\hline Grammar $(\mathrm{SI})$-Pronunciation $(\mathrm{SI})$ & $.528(\mathrm{p}<0.01)$ \\
\hline Grammar $(\mathrm{Cl})$-Pronunciation $(\mathrm{Cl})$ & $.627(\mathrm{p}<0.01)$ \\
\hline Content Accuracy $(\mathrm{SI})$-Celebrity Interpreter $(\mathrm{SI})$ & $-.423(\mathrm{p}<0.01)$ \\
\hline
\end{tabular}

Participants working for larger organizations were more demanding in terms of interpreter quality. Respondents working for organizations with 100 or more employees placed higher importance on accuracy, terminology, and grammar compared to those working for organizations with less than 30 employees (see Table 8).

Participants offered a more detailed view on the importance of interpreting quality for overall communicative experience and what constitutes quality interpreting. Most of the comments were on terminology, domain knowledge, accuracy, and language skills.

I happened to listen to simultaneous interpreting many times at seminars and conferences. I found that individual interpreter's competence actually determines the quality of the seminar itself. For conferences dealing with specialized topics, I think having an in-depth knowledge of that field is a must for quality interpreting. I often see some interpreters interpret terminology using ambiguous words. (Participant 82)

Based on my experience with simultaneous interpreting, there were too many omissions. Moreover, terminology was interpreted inaccurately. (Participant 52) 
A good interpreter should provide accurate interpreting. Then, he/she should have a good command of language, using the right wording based on the situation and context. (Participant 97)

Table 8: Importance of interpreting quality by organization size

\begin{tabular}{|c|c|c|c|c|}
\hline \multirow[t]{2}{*}{ Item } & \multirow[t]{2}{*}{$\begin{array}{ll}\mathrm{SI} / \\
\mathrm{Cl}\end{array}$} & \multicolumn{3}{|c|}{$\begin{array}{c}\text { Number of Employees (Organization Size) } \\
\text { Avg. (S.D.) }\end{array}$} \\
\hline & & $<30$ & $\geq 30,<100$ & $\geq 100$ \\
\hline \multirow[t]{4}{*}{ Accuracy } & \multirow[t]{2}{*}{$\mathrm{SI}$} & $4.3125(.6445)$ & $4.3704(.6293)$ & $\begin{array}{l}4.6600 \\
(.5573)\end{array}$ \\
\hline & & \multicolumn{3}{|c|}{$\begin{array}{l}\text { Significant difference: } \chi 2=8.16, p=.017, d f=2 \\
\text { Pairwise comparison: } 100+>1-29(p=.029)\end{array}$} \\
\hline & \multirow[t]{2}{*}{$\mathrm{Cl}$} & $4.3125(.7803)$ & $4.1481(.9074)$ & $\begin{array}{l}4.6200 \\
(.6354)\end{array}$ \\
\hline & & \multicolumn{3}{|c|}{$\begin{array}{l}\text { Significant difference: } \chi 2=7.21, p=.027, d f=2 \\
\text { Pairwise comparison: } 100+>1-29(p=.039)\end{array}$} \\
\hline \multirow[t]{4}{*}{$\begin{array}{c}\text { Terminol } \\
\text { ogy }\end{array}$} & \multirow[t]{2}{*}{$\mathrm{SI}$} & $4.2188(.7507)$ & $4.4444(.8006)$ & $\begin{array}{l}4.6600 \\
(.6263)\end{array}$ \\
\hline & & \multicolumn{3}{|c|}{$\begin{array}{l}\text { Significant difference: } \chi 2=9.35, p=.009, d f=2 \\
\text { Pairwise comparison: } 100+>1-29(p=.007)\end{array}$} \\
\hline & \multirow[t]{2}{*}{$\mathrm{Cl}$} & $4.0938(.8175)$ & $4.4444(.8473)$ & $\begin{array}{l}4.6000 \\
(.5714)\end{array}$ \\
\hline & & \multicolumn{3}{|c|}{$\begin{array}{l}\text { Significant difference: } \chi 2=8.91, p=.012, d f=2 \\
\text { Pairwise comparison: } 100+>1-29(p=.011)\end{array}$} \\
\hline \multirow[t]{2}{*}{ Grammar } & \multirow[t]{2}{*}{$\mathrm{SI}$} & $3.5000(.6720)$ & $3.5926(.8884)$ & $\begin{array}{l}3.9200 \\
(.8041)\end{array}$ \\
\hline & & \multicolumn{3}{|c|}{$\begin{array}{l}\text { Significant difference: } \chi 2=7.33, p=.026, d f=2 \\
\text { Pairwise comparison: } 100+>1-29(p=.026)\end{array}$} \\
\hline
\end{tabular}

\subsection{Interpreting as a business service}

Aside from interpreting quality, participants also valued their experience with interpreting as a business service. For the participants, fast responses to inquiries, systematic quotation and invoicing, communication about service details, a customer-friendly attitude, and a speedy recruitment process were all important considerations (see Table 9). This indicates that users saw interpreting as a business service that required not only quality interpreting performance, but also an efficient and pleasant administrative process, in other words, an end-to-end service.

Table 9: Interpreting as a business service

\begin{tabular}{|l|c|c|}
\hline \multicolumn{1}{|c|}{ Item } & $\begin{array}{c}\text { SI } \\
\text { Avg. (S.D.) }\end{array}$ & $\begin{array}{c}\text { Cl } \\
\text { Avg. (S.D.) }\end{array}$ \\
\hline Fast response to inquiries & $4.0367(.5762)$ & $4.0000(.7071)$ \\
\hline Systematic quotation and invoicing & $4.0367(.6794)$ & $4.0092(.6871)$ \\
\hline Communication of service details & $4.1009(.6519)$ & $4.0275(.7386)$ \\
\hline Customer-friendly attitude & $3.9633(.7191)$ & $3.9083(.7396)$ \\
\hline Speedy recruitment process & $3.9541(.6720)$ & $3.8716(.7214)$ \\
\hline
\end{tabular}


Respondents with more than 16 years of work experience had a clear preference for interpreting-as-a-service approach compared to the group with 610 years of experience. Table 10 shows a statistically significant difference between the two groups using Kruskal-Wallis test.

Table 10: Preference for interpreting-as-a-service by work experience

\begin{tabular}{|c|c|c|}
\hline Item & $\begin{array}{c}16 y+ \\
\text { Avg. (S.D.) }\end{array}$ & $\begin{array}{c}\text { 6-10y } \\
\text { Avg. (S.D.) }\end{array}$ \\
\hline \multirow{2}{*}{$\begin{array}{l}\text { Communication of service } \\
\text { details }(\mathrm{SI})\end{array}$} & $4.3913(.5830)$ & $3.9429(.5913)$ \\
\hline & \multicolumn{2}{|c|}{$\begin{array}{l}\text { Significant difference: } \chi 2=8.03, p=.045, d f=3 \\
\text { Pairwise comparison: } 16 y+>6-10 y(p=.046)\end{array}$} \\
\hline \multirow[t]{2}{*}{ Customer-friendly attitude (SI) } & $4.3043(.7029)$ & $3.8000(.5841)$ \\
\hline & \multicolumn{2}{|c|}{$\begin{array}{l}\text { Significant difference: } \chi 2=10.43, p=.015, d f=3 \\
\text { Pairwise comparison: } 16 y+>6-10 y(p=.030)\end{array}$} \\
\hline \multirow{2}{*}{$\begin{array}{l}\text { Systematic quotation and } \\
\text { invoicing }(\mathrm{Cl})\end{array}$} & $4.3478(.5728)$ & $3.8571(.7334)$ \\
\hline & \multicolumn{2}{|c|}{$\begin{array}{l}\text { Significant difference: } \chi 2=8.04, p=.045, d f=3 \\
\text { Pairwise comparison: } 16 y+>6-10 y(p=.046)\end{array}$} \\
\hline
\end{tabular}

Significant differences were also found between participants from large and small organizations. Respondents from organizations with 100 or more employees placed more importance on interpreting-as-a-service items compared to those from smaller organizations with less than 30 employees, suggesting the larger organizations' preference for systematic service provision (see Table 11 below).

Table 11: Preference for interpreting-as-a-service by organization size

\begin{tabular}{|c|c|c|c|}
\hline \multirow[t]{2}{*}{ Item } & \multicolumn{3}{|c|}{$\begin{array}{l}\text { Number of Employees } \\
\text { Avg. (S.D.) }\end{array}$} \\
\hline & $<30$ & $\geq 30,<100$ & $\geq 100$ \\
\hline \multirow{2}{*}{$\begin{array}{l}\text { Fast response to } \\
\text { inquiries }(\mathrm{Cl})\end{array}$} & $3.7813(.7064)$ & $3.8889(.8006)$ & $4.2000(.6061)$ \\
\hline & \multicolumn{3}{|c|}{$\begin{array}{l}\text { Significant difference: } \chi 2=8.43, p=.015, \mathrm{df}=2 \\
\text { Pairwise comparison: } 100+>1-29(p=.015)\end{array}$} \\
\hline \multirow{2}{*}{$\begin{array}{l}\text { Systematic } \\
\text { quotation and } \\
\text { invoicing }(\mathrm{Cl})\end{array}$} & $3.7188(.7289)$ & $4.0000(.7338)$ & $4.2000(.5714)$ \\
\hline & \multicolumn{3}{|c|}{$\begin{array}{l}\text { Significant difference: } \chi 2=9.40, p=.009, \mathrm{df}=2 \\
\text { Pairwise comparison: } 100+>1-29(p=.007)\end{array}$} \\
\hline \multirow{2}{*}{$\begin{array}{l}\text { Communication of } \\
\text { service details (SI) }\end{array}$} & $3.8125(.5923)$ & $4.2222(.6980)$ & $4.2200(.6158)$ \\
\hline & \multicolumn{3}{|c|}{$\begin{array}{l}\text { Significant difference: } \chi 2=9.80, p=.007, d f=2 \\
\text { Pairwise comparison: } 100+>1-29(p=.011)\end{array}$} \\
\hline \multirow{2}{*}{$\begin{array}{l}\text { Customer-friendly } \\
\text { attitude }(\mathrm{Cl})\end{array}$} & $3.6875(.8206)$ & $3.7037(.6086)$ & $4.1600(.6809)$ \\
\hline & \multicolumn{3}{|c|}{$\begin{array}{l}\text { Significant difference: } \chi 2=11.48, p=.003, d f=2 \\
\text { Pairwise comparison: } 100+>1-29(p=.019) \\
100+>30-99(p=.012)\end{array}$} \\
\hline
\end{tabular}

Excerpts of the comments from the open-ended questions are presented below:

I wish there were an integrated site where we can find and recruit professional interpreters based on detailed information. (Participant 29)

A consultancy network focusing on interpreting service is necessary. (Participant 88) 
We are seeing the rapid advance of machine translation technology. If users still prefer human interpreters, that's because they expect customer friendly and quality service from them. (Participant 99)

\section{6. $P R$}

An end-to-end service clearly did not include online PR efforts, in the view of the participants. When asked whether PR efforts, in terms of operating a website or promoting one's services through social media channels, were important signals, respondents offered negative views. Mean scores for website operation were $2.7339(\mathrm{SD}=0.9194)$ for SI and $2.7615(\mathrm{SD}=0.9898)$ for CI. Mean scores for social media promotion channels were $2.5229(\mathrm{SD}=0.9963)$ for $\mathrm{SI}$ and 2.6606 ( $\mathrm{SD}=1.0020)$ for CI. While participants valued any business efforts related to the core activities of interpreting (see Section 4.5), the above results clearly show that website and social media platform-based PR efforts were not perceived as important signals. Participants seemed to be quite pragmatic in their choices for interpreters, focusing on signals directly related to interpreting quality or administrative efficiency. Considering that postings on social media channels and websites advertise self-proclaimed competencies, users may not have perceived these assertions as direct proof of a quality interpreting service.

\subsection{Interpreter sourcing}

Receiving a recommendation would be one of the common ways to recruit an interpreter when clients do not have direct access to an interpreter network. However, participants of this survey were neutral as to whether recommendations are important signals, whether they be recommendations from their personal networks or commercial interpreting agencies, or headhunters (see Table 12).

Table 12: Interpreter sourcing

\begin{tabular}{|l|c|c|}
\hline \multicolumn{1}{|c|}{ Item } & $\begin{array}{c}\text { SI } \\
\text { Avg. (S.D.) }\end{array}$ & $\begin{array}{c}\text { Cl } \\
\text { Avg. (S.D.) }\end{array}$ \\
\hline Recommendation from personal sources & $3.0917(.8771)$ & $3.2385(.8596)$ \\
\hline $\begin{array}{l}\text { Recommendation from commercial } \\
\text { interpreting agencies, headhunters, etc. }\end{array}$ & $2.9817(.7815)$ & $3.1193(.8358)$ \\
\hline
\end{tabular}

\subsection{Other non-quality factors}

In stark contrast to the participants' preference for signals of interpreting quality, non-quality signals such as the appearance and celebrity-status of the interpreter did not garner much attention from the respondents. When asked whether interpreters should have good looks and a mainstream or social media presence, participants responded negatively in relation to both items. Mean scores for appearance were $2.5872(\mathrm{SD}=0.9927)$ for $\mathrm{SI}$ and $2.6514(\mathrm{SD}=$ 0.9849 ) for CI. Mean scores for celebrity interpreters were 2.3303 (SD = 1.0097) for SI and $2.4771(\mathrm{SD}=0.9487)$ for CI.

While the mean scores were low, the correlations between appearance, celebrity interpreter, and social media promotion were high, indicating that participants perceived these non-quality factors to be closely related (see Table 13). 
Table 13: Correlation between non-quality items

\begin{tabular}{|c|c|}
\hline Item pair & Correlation coefficient \\
\hline Celebrity interpreter $(\mathrm{Cl})$-Social media promotion $(\mathrm{Cl})$ & $.630(p<0.01)$ \\
\hline Appearance $(\mathrm{Cl})$-Social media promotion $(\mathrm{Cl})$ & $.601(p<0.01)$ \\
\hline Appearance $(\mathrm{Cl})$-Celebrity interpreter $(\mathrm{Cl})$ & $.715(p<0.01)$ \\
\hline Appearance $(\mathrm{Cl})$-Celebrity interpreter $(\mathrm{SI})$ & $.601(p<0.01)$ \\
\hline Celebrity interpreter (SI)-Social media promotion (SI) & $.674(p<0.01)$ \\
\hline Appearance $(\mathrm{SI})$-Celebrity interpreter $(\mathrm{SI})$ & $.636(p<0.01)$ \\
\hline Website promotion (SI)-Social media promotion (SI) & $.730(p<0.01)$ \\
\hline Appearance $(\mathrm{Cl})$-Appearance $(\mathrm{SI})$ & $.817(p<0.01)$ \\
\hline
\end{tabular}

Age is another non-quality factor that presented a peculiar landscape. Participants were asked to check all the age groups of interpreters they preferred. The results indicated that respondents most preferred the 30-39 age group for both SI and CI, followed by 40-49 age group, and the group with no age preference. The preference for the 20-29 age group was low and for the 5059 age group was even lower (see Table 14).

Table 14: Age preference (Multiple answers allowed)

\begin{tabular}{|c|c|c|c|c|}
\hline \multirow{2}{*}{ Age } & \multicolumn{2}{|c|}{ SI } & \multicolumn{2}{c|}{$\mathbf{C l}$} \\
\cline { 2 - 5 } & $\begin{array}{c}\text { Number of } \\
\text { responses } \\
(\mathbf{N = 1 0 9 )}\end{array}$ & $\begin{array}{c}\text { \% of total } \\
\text { participants }\end{array}$ & $\begin{array}{c}\text { Number of } \\
\text { responses } \\
(\mathbf{N = 1 0 9 )}\end{array}$ & $\begin{array}{c}\text { \% of total } \\
\text { participants }\end{array}$ \\
\hline $20-29$ & 16 & $14.7 \%$ & 17 & $15.6 \%$ \\
\hline $30-39$ & 71 & $65.1 \%$ & 64 & $58.7 \%$ \\
\hline $40-49$ & 43 & $39.4 \%$ & 44 & $40.4 \%$ \\
\hline $50-59$ & 3 & $2.8 \%$ & 4 & $3.7 \%$ \\
\hline $\begin{array}{c}\text { No preference } \\
\text { (Age doesn't } \\
\text { matter) }\end{array}$ & 25 & $22.9 \%$ & 31 & $28.4 \%$ \\
\hline
\end{tabular}

By gender, male participants' preferences were more concentrated on the 30 39 age group for both SI and CI, while female participants' responses were spread almost equally between 30-39 and 40-49 groups. Both genders' preferences for the youngest and oldest age groups were low.

Table 15: Age preference by gender (Multiple answers allowed)

\begin{tabular}{|c|c|c|c|c|}
\hline \multirow{2}{*}{ Age } & \multicolumn{2}{|c|}{ SI } & \multicolumn{2}{|c|}{ Cl } \\
\cline { 2 - 5 } & $\begin{array}{c}\text { Male (N=60) } \\
\text { No. (\%) }\end{array}$ & $\begin{array}{c}\text { Female } \\
\mathbf{( N = 4 9 )} \\
\text { No. (\%) }\end{array}$ & $\begin{array}{c}\text { Male (N=60) } \\
\text { No. (\%) }\end{array}$ & $\begin{array}{c}\text { Female } \\
\mathbf{( N = 4 9 )} \\
\text { No. (\%) }\end{array}$ \\
\hline $20-29$ & $9(15.0 \%)$ & $7(14.3 \%)$ & $11(18.3 \%)$ & $6(12.2 \%)$ \\
\hline $30-39$ & $46(76.7 \%)$ & $25(51.0 \%)$ & $40(66.7 \%)$ & $24(49.0 \%)$ \\
\hline $40-49$ & $19(31.7 \%)$ & $24(49.0 \%)$ & $21(35.0 \%)$ & $23(46.9 \%)$ \\
\hline $50-59$ & $2(3.3 \%)$ & $1(2.0 \%)$ & $2(3.3 \%)$ & $2(4.1 \%)$ \\
\hline $\begin{array}{c}\text { No preference } \\
\text { (age doesn't } \\
\text { matter) }\end{array}$ & $9(15.0 \%)$ & $16(32.7 \%)$ & $13(21.7 \%)$ & $18(36.7 \%)$ \\
\hline
\end{tabular}




\subsection{Ethics and professional conduct}

Participants perceived ethics and professional conduct as important factors. When asked whether professional ethics ${ }^{2}$ was an important consideration in interpreter recruitment, respondents gave mean scores of $4.0642(\mathrm{SD}=0.6565)$ for SI and $4.0734(\mathrm{SD}=0.7291)$ for CI. The mean scores for professional conduct, such as good attitudes and social skills, were $3.8807(\mathrm{SD}=0.7543)$ for $\mathrm{SI}$ and $3.8532(\mathrm{SD}=0.7555)$ for CI. Interestingly, the perceived importance of ethics grew with the length of the participant's career (see Table 16).

Table 16: Perceived importance of ethics by length of career

\begin{tabular}{|c|c|c|}
\hline $\begin{array}{c}\text { Career } \\
\text { length }\end{array}$ & SI (SD) & CI (SD) \\
\hline $1-5$ years & $3.8438(.6278)$ & $3.8750(.7513)$ \\
\hline $6-10$ years & $4.0286(.5681)$ & $3.9429(.6835)$ \\
\hline $11-15$ years & $4.1579(.6883)$ & $4.1053(.6578)$ \\
\hline $\begin{array}{c}16 \text { years } \\
\text { and longer }\end{array}$ & $4.3478(.7141)$ & $4.5217(.6654)$ \\
\hline
\end{tabular}

The Kruskal-Wallis test revealed statistically significant differences in ethics perception by career length (SI: $\chi^{2}=8.62, p=.035, \mathrm{df}=3$, CI: $\chi^{2}=13.04, p=.005$, $\mathrm{df}=3$ ), and a pairwise comparison showed differences between the "16 years and longer" group and the " $1-5$ years" group for SI $(\mathrm{p}=.027)$ and for CI $(\mathrm{p}=.005)$. Significant differences were also found between the "16 years and longer" group and the " $6-10$ years" group for CI $(\mathrm{p}=.012)$. Significant differences were also found based on organization size (CI: $\chi^{2}=8.26, p=.016$, $\mathrm{df}=2$ ). A pairwise comparison revealed significant differences between participants working for organizations with 100 or more employees and those with less than 30 employees $(\mathrm{p}=.012)$.

\subsection{Price preference}

The mean prices for SI and CI that participants were willing to pay were close to the standard rate in the South Korean market, with an average rate of 951,468 KRW [788.62 USD] per day for SI and 871,927 KRW [722.69 USD] per day for CI. ${ }^{3}$ The distribution of rate preference is presented in Figure 1. Price preferences between SI and CI were also highly correlated $(\mathrm{r}=.837, \mathrm{p}<0.01)$.

\footnotetext{
2 This, in this context, refers to professional ethics in general, and does not refer to a specific professional code of conduct.

${ }^{3}$ This is based on the currency exchange rate as of March 12, $2020(1 \mathrm{USD}=1206.50$ KRW).
} 


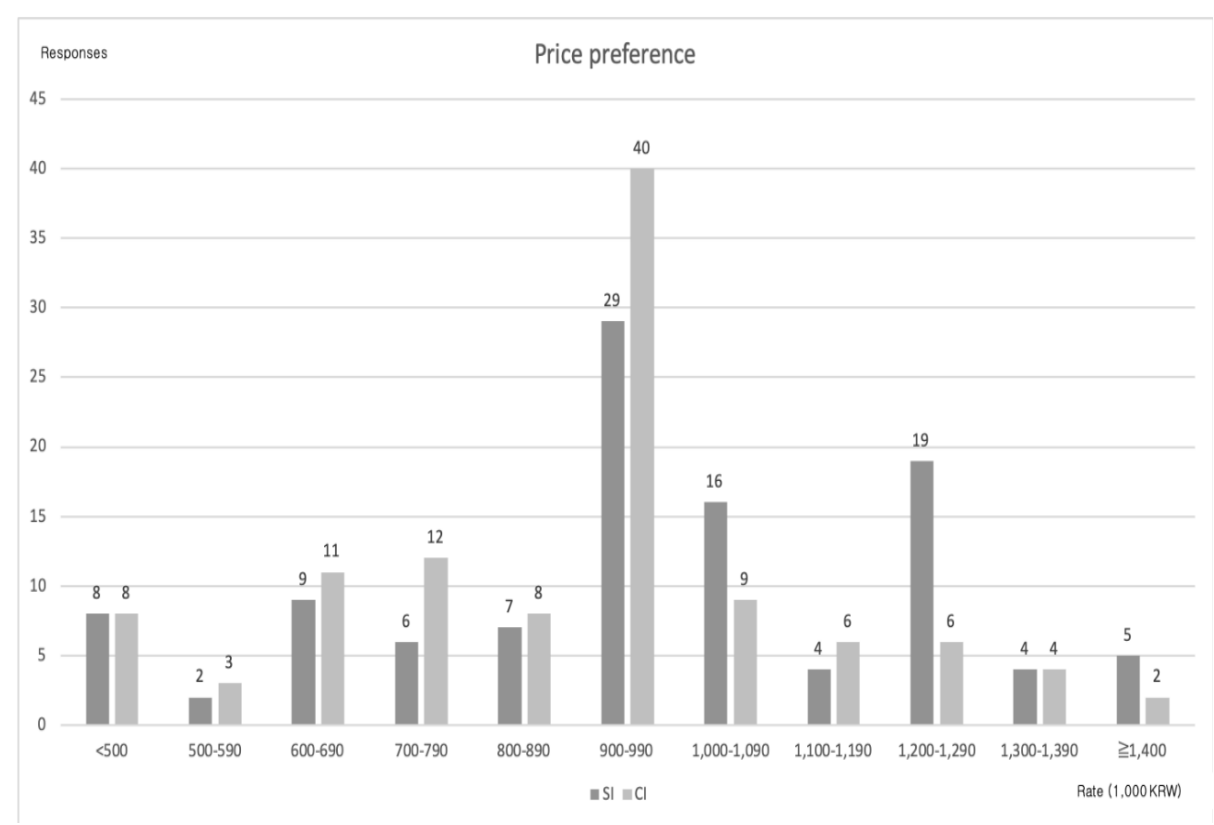

Figure 1: Price preference

Most participants chose the rate bracket around the standard rate $(900,000 \mathrm{KRW}$ [745.96 USD]) for both SI and CI. However, there were subtle differences in the price choices between SI and CI. Regarding SI, while $26.6 \%(n=29)$ of the participants were willing to pay at standard rates of 900,000 [745.96 USD]990,000 KRW [820.56 USD], more participants, $(44.0 \%, \mathrm{n}=48)$ were willing to pay more than the standard rate. On the other hand, 29.4\% $(\mathrm{n}=32)$ of respondents wanted to pay less than the standard rate. For CI, 36.7\% $(n=40)$ of the participants, which was higher than the number for SI, were willing to pay the standard rate. But only $24.8 \%(\mathrm{n}=27)$ of respondents were willing to pay more than the standard rate, while $38.5 \%(n=42)$ of participants wanted to pay less than the standard rate. While, for CI, participants' responses were concentrated on the standard rate, in the case of SI, more respondents were willing to pay higher than the standard rate band. This suggests that respondents perceived SI to be a higher-value service than CI.

\subsection{Assessment of interpreting service needs}

Participants were asked which type of events would require a professional interpreting service. An overwhelming percentage of respondents chose international conferences and seminars $(\mathrm{n}=98,89.9 \%)$, which was followed, albeit distantly, by business meetings with other organizations $(n=69,63.3 \%)$ and escort interpreting $(\mathrm{n}=68,62.4 \%)$. Many respondents also chose academic conferences $(n=44,40.4 \%)$, negotiations $(n=42,38.5 \%)$, and video conferencing and conference calls $(n=41,37.6 \%)$. The results suggest that participants viewed large, formal events (international conferences), escorting high-profile figures (escort interpreting), events requiring expert domain knowledge (academic conferences), and high-stakes business meetings 
(meetings with external organizations, negotiations, or conference calls) as important events that would require professional interpreters (see Table 17).

Table 17: Assessment of interpreting service needs (Multiple answers allowed)

\begin{tabular}{|l|c|c|}
\hline Needs & $\begin{array}{c}\text { Number of responses } \\
(\mathrm{N}=109)\end{array}$ & $\%$ of total participants \\
\hline $\begin{array}{l}\text { International } \\
\text { conferences/seminars }\end{array}$ & 98 & $89.9 \%$ \\
\hline $\begin{array}{l}\text { Business meetings with external } \\
\text { partners }\end{array}$ & 69 & $63.3 \%$ \\
\hline Escort interpreting & 68 & $62.4 \%$ \\
\hline Academic conference & 44 & $40.4 \%$ \\
\hline Negotiations video & 42 & $38.5 \%$ \\
\hline $\begin{array}{l}\text { Conference call, } \\
\text { conference }\end{array}$ & 41 & $37.6 \%$ \\
\hline Press conference/interview & 37 & $33.9 \%$ \\
\hline Training, workshop & 32 & $29.4 \%$ \\
\hline IR (Investor relations) & 30 & $25.5 \%$ \\
\hline Field trip & 28 & $20.2 \%$ \\
\hline Executive meeting & 22 & $19.3 \%$ \\
\hline Courtesy visit & 21 & $19.3 \%$ \\
\hline Luncheon, gala dinner & 21 & $10.1 \%$ \\
\hline Internal business meetings & 11 & \\
\hline
\end{tabular}

\section{Discussion}

This paper has explored signals related to professional interpreting services based on the results of an online questionnaire. The findings of the survey indicated that respondents were highly interested in searching for competent interpreters capable of delivering quality interpreting based on domain-specific experience and an adherence to professional ethics. Respondents particularly placed very high importance on quality factors relating to the faithfulness of meaning, such as content accuracy, completeness, and correct use of specialized terminology. They also highly valued language skills, such as grammar and pronunciation, albeit to a lesser degree. Participants working for large organizations were noticeably more interested in interpreting quality, such as content accuracy, terminology and grammar, than those from small organizations. Furthermore, respondents were overwhelmingly interested in whether interpreters possessed domain-specific experience and knowledge, and these were valued more than whether they had interpreted for high-profile individuals or at prestigious conferences. In other words, what mattered most to respondents was how well interpreters were able to interpret at "their" events, not those of "others." Such an attitude reflected respondents' keen focus on interpreting quality, the key ingredient for successful communication. Based on my survey findings, the kinds of events that require professional conference interpreters were international conferences and seminars, high-stakes business meetings, high-profile escort interpreting, and academic conferences.

Quality interpreting, however, cannot be achieved only with extensive knowledge of the subject matter and terminology. It requires a diverse array of 
interpreting skills including linguistic skills, comprehension, reproduction skills, coordination, and memory. The problem is that it is not easy for users to identify these multifaceted competency features, which is why they look for straightforward and easily comprehensible evidence. Since users focus on direct signals, even word-of-mouth referrals, which usually provide useful signals in the service industry, are not helpful. Naturally, users search for signals that might be able to guarantee the minimum level of professional service that they can expect from interpreters, one of which would be interpreter certification. Although the types of preferred certification systems vary, participants generally expressed a preference for a certification system operated by a reliable organization with authority, such as a widely recognized interpreters' association, the state, or government departments.

However, an academic degree in interpreting was not particularly valued by survey participants, even though the general path to becoming a conference interpreter in South Korea is completion of an interpreting program at a graduate school for interpretation (Kim, Park \& Hong, 2019; Korea Research Institute for Vocational Education \& Training, n.d.). Earning a master's degree in conference interpreting is not an easy task-requiring two years of intensive skills development in consecutive and simultaneous interpreting. Due to the high competition, it is difficult to pass the entrance exam, and this is especially true for prestigious programs in South Korea. Despite the efforts that interpreters invest in acquiring professional interpreting skills, the survey results revealed that respondents did not regard a master's degree in interpreting as a strong signal. Judging by the participants' preference for direct signals, an academic degree might be associated with a variety of indirect information which makes it too complicated for them to set priorities. Still, considering that it requires years of training and practice to acquire good interpreting skills, the value of training should be promoted to a wider audience so that interpreters' training background will function as a useful and tangible signal that users can rely on. This is also important for interpreting as a profession, since education and training are important elements that determine the degree of professionalization (Dam \& Zethsen, 2013, p. 233).

Again, the importance of quality is echoed in participants' lack of interest in social media publicity and appearance. Interpreters' social media activities appear to be a new trend for marketing interpreting services, and this has raised concerns about aesthetic labor. However, these features do not seem to serve as useful signals for users in the study reported on here because they are not direct indicators of professional interpreting services. Unfortunately, participants' preference for an interpreter's age seems to run counter to their high level of concern with interpreting quality. Participants appeared to overwhelmingly prefer interpreters in their $30 \mathrm{~s}$, and to a lesser degree, those in their 40s. Preference for interpreters in their 50s or older was low in comparison. This pattern was more pronounced among male as opposed to female participants, adding concerns of ageism and a gendered market structure. This finding can also be understood within a larger context of the Korean labor market, where the preference for younger workers is prominent. Korean firms perceive that worker productivity peaks at 40 , which is earlier than the peak age perceived in other countries (Ji, 2017). The worker age distribution for high added-value 
service sectors, such as ICT, professional services, science and technology services, financial services, and education services, is concentrated around workers between the 25-44 age group in South Korea (Kim et al., 2019).

The results raise some concerns for the profession. While participants' emphasis on competency and experience is a welcome sign in terms of professionalization of the interpreting profession, the extremely low preference for interpreters aged 50 years or older presents a concern. Considering that interpreters, like other professions, acquire knowledge and expertise with experience, the higher age groups' expertise is invaluable. However, the lower demand for interpreters in the higher age bracket might lead to a decline in the supply of competent interpreters in that age group - contributing to a shorter life span in the profession. This contrasts with the situation in DG SCIC (Directorate-General for Interpretation of the European Commission), where the average age of their interpreters is around 48, and their imperative is to recruit younger generations to continue the service (Duflou, 2016, p. 127).

The findings present a rather complex landscape. While participants reported being eager to recruit highly qualified interpreters, some of the signals that they preferred or not show that they may not be looking for the right selection criteria. This apparent inconsistency may be, in part, due to the lack of information regarding proper qualifications for professional interpreting services. The price range preferred by participants is a case in point. In this study, many participants reported being willing to pay more than the reference price for simultaneous interpreting services. In the service industry, where advance verification of service quality is difficult, lack of information can lead to a price-quality association (Ding, Ross \& Rao, 2010; Lambert, 1972; Rao \& Monroe, 1988; Stiglitz, 1987). In other words, because it is difficult for users to predict the level of professional interpreting services by another means, they may resort to price as the key criterion associated with service quality. At the same time, this finding also indicates that users value interpreting as a professional service and that many appear willing to pay a fair price.

The strong demand for quality signals and the lack of information for users bring us back to the need for establishing an adequate interpreter certification system to guarantee a minimum acceptable level of interpreting quality. Other signals, such as domain knowledge, interpreting experience, and academic background can be considered in combination in the search for users' interpreter of choice. Furthermore, it would be worthwhile to also consider developing a service process approach to interpreting. The participants' reported demand for fast responses, systematic quotation and invoicing, communication of service details, a customer-friendly attitude, and speedy recruitment process suggests that a systematic service-based approach is required. Such a preference was more pronounced among participants with lengthy work experience and those working for large organizations. In fact, these groups of respondents reported being interested in the overall end-to-end excellence, placing high expectations on ethics, general interpreting experience, and interpreting quality. If interpreting were to be understood and provided as an end-to-end serviceencompassing service inquiry, quotation, consultation, assignment, preparatory work, delivery (interpreting), quality assessment and management, feedback, post-job operations, and invoicing - service providers would be able to better 
serve user demand and facilitate the development of a systematic signaling process. Continuous quality assessment, feedback, and consultation steps will help build a virtuous signal-building cycle. This may also produce more interaction between clients and interpreters, helping them understand each other's needs for a better outcome, thereby creating a collaborative relationship. Such an approach may help create better business opportunities and foster entrepreneurial endeavors, expanding the market for all and building a sustainable industry.

\section{Conclusion}

This paper explored key signaling factors affecting user demand, such as interpreter credentials, interpreting quality, and service elements. The findings indicate that interpreting quality, such as content accuracy, completeness, and terminology, are the most important considerations. This suggests that users' awareness of the importance of quality and the main function of interpreting as a communicative act is very high. The weak signaling power of an academic degree in interpreting, however, casts concerns of information asymmetry and calls for more efforts to keep users informed of the importance of professional training for nurturing quality interpreters.

The findings also point to the changing demand for interpreting. It is imperative that we consider the "interpreting as a service" approach based on an end-to-end service concept in both practice and training. Curriculum design should also reflect the changing demands in terms of the type of conference or meeting settings that require professional interpreting service, enabling situated learning activities beyond the traditional mock conference settings.

This study was conducted using a limited sample size and findings thus cannot be generalized. The quantitative approach to the survey left room for further investigation on certain topics, such as ageism and relationship building between interpreters and users, and calls for a follow-up study based on the qualitative approach to explore the in-depth details behind the results of this study. Despite the limitations mentioned above, this paper is meaningful because it explored concrete elements of the user demand in the South Korean context and identified key qualification signals, which are important for users as they search for professional interpreters.

\section{Funding}

This work was supported by the Ewha Womans University Research Grant of 2018.

\section{References}

Bansal, H. S., \& Voyer, P. A. (2000). Word-of-mouth processes within a services purchase decision context. Journal of Service Research, 3(2), 166-177.

Berry, L. L. (1980). Services marketing is different. Business, 30(3), 24-29. 
Biswas, A., Pullig, C., Krishnan, B. C., \& Burton, S. (1999). Consumer evaluation of reference price advertisements: Effects of other brands' prices and semantic cues. Journal of Public Policy \& Marketing, 18(1), 52-65.

Bühler, H. (1986). Linguistic (semantic) and extra-linguistic (pragmatic) criteria for the evaluation of conference interpretation and interpreters. Multilingua, 5(4), 231235.

Chan, A. L. J. (2009). Effectiveness of translator certification as a signaling device: Views from the translator recruiters. Translation and Interpreting Studies, 4(2), 155-171. doi: 10.1075/tis.4.2.06cha

Cho, J. (2017). English language ideologies in Korea: Interpreting the past and present. Cham: Springer.

Dagger, T. S., \& Sweeney, J. C. (2007). Service quality attribute weights: How do novice and longer-term customers construct service quality perceptions? Journal of Service Research, 10(1), 22-42.

Dam, H. V., \& Zethsen, K. K. (2013). Conference interpreters-the stars of the translation profession?: A study of the occupational status of Danish EU interpreters as compared to Danish EU translators. Interpreting, 15(2), 229-259.

Ding, M., Ross Jr, W. T., \& Rao, V. R. (2010). Price as an indicator of quality: Implications for utility and demand functions. Journal of Retailing, 86(1), 69-84.

Duflou, V. (2016). Be (com) ing a conference interpreter. Amsterdam/Philadelphia: John Benjamins.

Du Tertre, C. (1999). Intangible and interpersonal services: Toward new political economy tools. The French case. Service Industries Journal, 19(1), 18-34.

Eser, O. (2020). Understanding community interpreting as a service. Cham: Palgrave Macmillan.

Freberg, K., Graham, K., McGaughey, K., \& Freberg, L. A. (2011). Who are the social media influencers? A study of public perceptions of personality. Public Relations Review, 37(1), 90-92.

Han, J. E. (2013). 'sayongja kwanjŏmŭi t'ongyŏk p'umjil p'yŏngga yŏn'gu - t'ongyŏk eijŏnsi ŏmmu tamdangjarŭl chungsimŭro' [A study of the quality assessment in interpreting from the user's perspective - Focused on the managers of interpreting agency] ( $\mathrm{PhD}$ thesis). Retrieved from http://www.riss.kr/search/detail/ DetailView.do?p_mat_type $=$ be 54d9b8bc7cdb09\&control_no=06b5a1bbff81006 effe0bdc3ef48d419\&outLink $=\mathrm{N}$

Hirschman, E. (1980). Attributes of attributes and layers of meaning. Advances in Consumer Research, 7, 7-12.

Huh, J. (2016). 'ŏllonbodoe t'uyŏngdoen tongsit'ongyŏge taehan koch'al' [Study on simultaneous interpretation as portrayed in news media]. t'ongyŏkkwa pŏnyŏk [Interpretation and Translation], 18(2), 153-187.

Jewell, J. (2014). Duty, professionalisation and nursing knowledge: What can veterinary nursing learn from the experiences of human nursing? Veterinary Nursing Journal, 29(11), 365-368. doi: 10.1111/vnj.12193

Ji, E. J. (2017). '60se isang koryŏnggŭllojaŭi saengsansŏnge taehan insigyŏn'gu: t'onggyejŏk ch'abyŏlgwa chŏpch'okkasŏrŭl chungsimŭro' [Perception of older workers' productivity: Focusing on the statistic discrimination and contact hypothesis]. Health and Social Welfare Review, 37(3), 73-109.

Jones, R. (2002). Conference interpreting explained. Manchester: St. Jerome.

Kahneman, D., \& Tversky, A. (1979). Prospect theory: An analysis of decisions under risk. Econometrica, 47, 263-291.

Kalina, S. (2005). Quality assurance for interpreting processes. Meta, 50(2), 768-784.

Kim, J. Y., Kim, W. K., Kim, I. C., Lim, S. Y., Cho, J. H., Gil, E. S., ...Lee, Y. H. (2019). 'in'gugujo pyŏnhwae ttarŭn sanŏpkujowa nodongsijang pyŏnhwa punsǒk mit chŏngch'aekkwaje' [Analysis of changes in industrial structure and labor

Translation \& Interpreting Vol. 13 No. 1 (2021) 
market caused by demographic change and policy challenges ahead]. Korea Institute for Industrial Economics \& Trade. Retrieved from http:/www.kiet. re.kr/kiet_web/index.jsp?sub_num $=8 \&$ ord $=0 \&$ pageNo $=2 \&$ state $=$ view $\&$ tab $=1$ list \&idx $=56 \overline{1} 88 \#$ none

Kim, H. A., Park, K. B., Hong, J. E. (2019, April 21). 'chintcha' kukchehoeŭi t'ongyŏksaga marhanŭn 't'ongyŏksaga toeryŏmyŏn?' [A 'real' interpreter speaks about 'How to become an interpreter?']. mŏnit'udei [Money Today]. Retrieved from https://news.naver.com/main/read.nhn?mode=LSD\&mid=sec\&sid1= 102\&oid $=008$ \&aid $=0004207056$

Kopalle, P. K., \& Lindsey-Mullikin, J. (2003). The impact of external reference price on consumer price expectations. Journal of Retailing, 79(4), 225-236.

Kopczynski, A. (1994). Quality in conference interpreting: Some pragmatic problems. In S. Lambert \& B. Moser-Mercer (Eds.), Bridging the gap: Empirical research in simultaneous interpretation (pp. 87-99). Amsterdam/Philadelphia: John Benjamins Publishing.

Korea Research Institute for Vocational Education \& Training. (n.d.). t'ongyŏkka [Interpreter]. Retrieved from https://terms.naver.com/entry.nhn?docId=926307 \&cid=42116\&categoryId=42116

Kurz, I. (1993). Conference interpretation: Expectations of different user groups. The Interpreters' Newsletter, 5, 13-21.

Kwak, J. C. (2004). 'chasusŏnggahyŏng t'ongyŏksa t'ongyŏge kwanhan sogo' [A study on Korean self-made interpreters' performances]. t'ongbŏnyŏkhagyŏn'gu [Interpreting and Translation Studies], 8, 1-38.

Lambert, Z. V. (1972). Price and choice behavior. Journal of Marketing Research, 9(1), 35-40.

Lin, O. C. (2015). The translation industry in Taiwan in the context of globalization: Facing the development of professional translation and Master of Translation and Interpreting. In L. Ko \& P. Chen (Eds.), Translation and cross-cultural communication studies in the Asia-Pacific (pp. 369-387). Boston: Brill Rodopi.

Lee, H. I. (2014). 'sǒbisŭ kogaegŭi simniwa haengdong' [Service customers' psychology \& behavior]. Seoul: Kimoonsa.

Lovelock, C., \& Gummesson, E. (2004). Whither services marketing? In search of a new paradigm and fresh perspectives. Journal of Service Research, 7(1), 20-41.

Marrone, S. (1993). Quality: A shared objective. The Interpreters' Newsletter, 5, 3541.

Mazumdar, T., \& Papatla, P. (2000). An investigation of reference price segments. Journal of Marketing Research, 37(2), 246-258.

Mikkelson, H. (2009, December 14). Interpreting is interpreting-Or is it? Aiic.net. Retrieved from http://aiic.net/p/3356

Monroe, K. B. (1973). Buyers' subjective perceptions of price. Journal of Marketing Research, 10(February), 70-80.

Moser, B. (1996). Expectations of users of conference interpretation. Interpreting 1(2), 145-178.

Na, S., Kunkel, T., \& Doyle, J. (2020). Exploring athlete brand image development on social media: The role of signaling through source credibility. European Sport Management Quarterly, 20(1), 88-108.

Orzan, G. (2016). Conceptual model regarding the influence of social media marketing communication on brand trust, brand affect and brand loyalty. Economic Computation and Economic Cybernetics Studies and Research, 50(1), 141-156.

Park, H. (2010, July 26). 't'ongyŏksa in'gi ch'urak... "urin ŏttŏkhae"” [Falling popularity of interpreters... "What shall we do?']. chugandonga [Weekly DongA]. Retrieved from https://weekly.donga.com/List/3/all/11/90391/1 
Park, J. (2016). 'inhausŭ t'ongbŏnyŏksaŭi koyong hyŏnhwanggwa chingmu punsŏk t'ongbŏnyŏk pijŏn'gongjarŭl chungsimŭro' [Employment and job analysis of inhouse translators \& interpreters - Focusing on translators \& interpreters without professional training]. pŏnyŏkhagyŏn'gu [The Journal of Translation Studies], 17(5), 127-152.

Park, S. W. (2019, March 22). 'albawa chŏnmunjik sai...t'ongyŏksa, chonjungbatchi mot'anŭn sŏnmangŭi taesang' [Between part-time job and a full-fledged profession...Interpreter, an object of envy but also an unrespected job]. kyŏnghyangsinmun [The Kyunghyang Shinmun]. Retrieved from https://news.naver.com/main/read.nhn?mode=LSD\&mid=sec\&sid1=103\&oid=0 32\&aid $=0002930134$

Pérez-González, L., \& Susam-Saraeva, Ş. (2012). Non-professionals translating and interpreting: Participatory and engaged perspectives. The Translator, 18(2), 149165.

Pöchhacker, F. (2011). Conference interpreting. In K. Malmkjær \& K. Windle (Eds.), The Oxford handbook of translation studies (pp. 307-324). Oxford: Oxford University Press.

Porter, M. C., Anderson, B., \& Nhotsavang, M. (2015). Anti-social media: Executive twitter 'engagement' and attitudes about media credibility. Journal of Communication Management, 19(3), 270-287.

Pym, A., Orrego-Carmona, D., \& Torres-Simón, E. (2016). Status and technology in the professionalization of translators. Market disorder and the return of hierarchy. The Journal of Specialised Translation, 25(1), 33-53.

Rao, A. R., \& Monroe, K. B. (1988). The moderating effect of prior knowledge on cue utilization in product evaluations. Journal of Consumer Research, 15(2), 253264.

Ryu, K., Lee, H. R., \& Gon Kim, W. (2012). The influence of the quality of the physical environment, food, and service on restaurant image, customer perceived value, customer satisfaction, and behavioral intentions. International Journal of Contemporary Hospitality Management, 24(2), 200-223.

Setton, R. (2010). Conference interpreting. In Y. Gambier \& L. Van Doorslaer (Eds.), Handbook of translation studies (pp. 66-74). Amsterdam/Philadelphia: John Benjamins Publishing.

Shostack, G. L. (1977). Breaking free from product marketing. Journal of Marketing, 41(2), 73-80.

Stiglitz, J. E. (1987). The causes and consequences of the dependence of quality on price. Journal of Economic Literature, 15(March), 1-48.

Spence, M. (1973). Job market signaling. Quarterly Journal of Economics, 87(3), 335374.

Tversky, A., \& Kahneman, D. (1974). Judgment under uncertainty: Heuristics and biases. Science, 185(4157), 1124-1131.

Viaggio, S. (June 29, 2016). The tribulations of a chief interpreter. AIIC. Retrieved from https://aiic.net/p/1324

Witter-Merithew, A., \& Johnson, L. (2004). Market disorder within the field of sign language interpreting: Professionalization implications. Journal of Interpretation, 14, 19-55.

Zeithaml, V. A., Parasuraman, A., \& Berry, L. L. (1985). Problems and strategies in services marketing. Journal of marketing, 49(2), 33-46. 


\section{Appendix: Questionnaire}

I. Screening questions

1. Have you ever received professional interpreting services over the last 5 years at work or on other occasions?

(* Professional interpreting refers to simultaneous or consecutive interpreting provided at a professional level at occasions such as, conferences, seminars, business meetings, internal meetings, business management meetings, shareholder meetings, video conferences, conference calls, negotiations, information sessions, press interviews, press conferences, due diligence, field trips, academic conferences, training, or workshops.

1) Yes ( $\rightarrow$ Go to Question 2)

2) No $(\rightarrow$ Disqualified: End of survey)

2. What is your occupation?

1) Interpreter or Translator ( $\rightarrow$ Disqualified: End of survey)

2) Student ( $\rightarrow$ Disqualified: End of survey)

3) None ( $\rightarrow$ Disqualified: End of survey)

4) Other $(\rightarrow$ Go to Section II)

II. Demographics

1. Which sector are you in?

1) Government, Public sector

2) ICT, Game

3) Manufacturing, Logistics, Sales

4) Accounting, Business, Finance, Law engineering

7) Healthcare

5) Media and Entertainment

8) Research \& Education
9) Others (Please specify:

2. Which of the following best describes the type of organization that you work for?

1) Private sector business

5) T\&I agency, PCO

2) Government, Public sector business

6) Freelancer

3) University, Research Institute

7) Self-employed

4) NGO, NPO, Social enterprise

8) Others (Please specify:

3. How many years of work experience do you have?

1) None ( $\rightarrow$ Disqualified: End of survey) 3 3) 1-5 years

2) Less than 1 year ( $\rightarrow$ Disqualified: End 4) 6-10 years

of survey)

5) $11-15$ years

6) 16 years or above

4. How many employees are there in the organization you work for?

1) Less than 30

2) $30-99$

3) 100 or more

5. Which of the following best matches your job title?

1) Staff

5) Executive

2) Assistant Mgr

6) $\mathrm{CEO}$

3) Section Chief

7) Others (Please specify:

4) Department Head

6. What is your age?

1) 19 or under ( $\rightarrow$ Disqualified: End of survey)

2) $20-29$

3) $30-39$

4) $40-49$

5) 50 or above 
7. What is your gender?

1) Male

2) Female

8. What language(s) can you speak?

1) English

9) Arabic

2) French

10) Malaysian/Indonesian

3) German

11) Thai

4) Russian

12) Turkish

5) Spanish

13) Hindi

6) Portuguese

7) Chinese

15) None

8) Japanese

9. Which of the following cases describe(s) your experience with the interpreting service you've received? Select all statements that match your opinion.

1) I have listened to interpreting from live TV broadcast or Youtube before

2) I have listened to interpreting at conferences, seminars, or academic conferences before.

3) I have listened to interpreting at work participating in business meetings or executive meetings before.

4) I have hired a staff interpreter for my organization before.

5) I have recruited freelance interpreters as an organizer of conferences or business meetings before.

6) I have recruited interpreters as an interpreting agent before.

7) Others (Please specify:

$$
\text { ) }
$$

10. In what language(s) have you received the interpreting service(s)?
1) English
8) Japanese
2) French
9) Arabic
3) German

10) Malaysian/Indonesian

4) Russian

5) Spanish

12) Turkish

6) Portuguese

7) Chinese

14) Others (Please specify:

III. Main Questions

A. Simultaneous interpreting

If your work requires a simultaneous interpreting service, how important do you think the following items would be? Check how strongly you agree to each of the following statements.

* Simultaneous interpreting refers to a mode of interpreting where interpreting is performed at the same time a speaker makes his/her utterances. Simultaneous interpreting requires the use of interpreting devices and equipment, and the audience wear receivers to listen to the interpreting output.

\begin{tabular}{|l|l|l|}
\hline No. & Items & \\
\hline 1 & $\begin{array}{l}\text { The interpreter should have a master's degree in } \\
\text { Interpreting. }\end{array}$ & $\begin{array}{l}\text { Strongly disagree-Disagree- } \\
\text { Neutral-Agree-Strongly agree }\end{array}$ \\
\hline 2 & $\begin{array}{l}\text { The interpreter should have a certificate in } \\
\text { professional interpreting that ensures one's } \\
\text { interpreting competency. }\end{array}$ & $\begin{array}{l}\text { Strongly disagree-Disagree- } \\
\text { Neutral-Agree-Strongly agree }\end{array}$ \\
\hline 3 & $\begin{array}{l}\text { The interpreter should have a lot of general } \\
\text { interpreting experience. }\end{array}$ & $\begin{array}{l}\text { Strongly disagree-Disagree- } \\
\text { Neutral-Agree-Strongly agree }\end{array}$ \\
\hline 4 & $\begin{array}{l}\text { The interpreter should have a lot of domain- } \\
\text { specific interpreting experience. }\end{array}$ & $\begin{array}{l}\text { Strongly disagree-Disagree- } \\
\text { Neutral-Agree-Strongly agree }\end{array}$ \\
\hline 5 & The interpreter should have a lot of interpreting & Strongly disagree-Disagree- \\
\hline
\end{tabular}




\begin{tabular}{|c|c|c|}
\hline & experience specific to my organization. & Neutral-Agree-Strongly agree \\
\hline 6 & $\begin{array}{l}\text { The interpreter should have a lot of interpreting } \\
\text { experience in high-profile events. }\end{array}$ & $\begin{array}{l}\text { Strongly disagree-Disagree- } \\
\text { Neutral-Agree-Strongly agree }\end{array}$ \\
\hline 7 & $\begin{array}{l}\text { The interpreter should be someone } \\
\text { recommended from my personal sources. }\end{array}$ & $\begin{array}{l}\text { Strongly disagree-Disagree- } \\
\text { Neutral-Agree-Strongly agree }\end{array}$ \\
\hline 8 & $\begin{array}{l}\text { The interpreter should be someone } \\
\text { recommended by commercial interpreting } \\
\text { agencies, headhunters, or PCOs. }\end{array}$ & $\begin{array}{l}\text { Strongly disagree-Disagree- } \\
\text { Neutral-Agree-Strongly agree }\end{array}$ \\
\hline 9 & $\begin{array}{l}\text { The interpreter should have good attitudes and } \\
\text { social skills. }\end{array}$ & $\begin{array}{l}\text { Strongly disagree-Disagree- } \\
\text { Neutral-Agree-Strongly agree }\end{array}$ \\
\hline 10 & The interpreter should have a sense of ethics. & $\begin{array}{l}\text { Strongly disagree-Disagree- } \\
\text { Neutral-Agree-Strongly agree }\end{array}$ \\
\hline 11 & The interpreter should have good appearance. & $\begin{array}{lr}\text { Strongly } & \text { disagree- } \mathrm{D} \\
\text { Neutral-Agree-Strongly a }\end{array}$ \\
\hline 12 & The interpreter should be a celebrity interpreter. & $\begin{array}{l}\text { Strongly disa } \\
\text { Neutral-Agree-Str }\end{array}$ \\
\hline 13 & $\begin{array}{l}\text { Responses to inquiries related to interpreting } \\
\text { services should be done speedily. }\end{array}$ & $\begin{array}{l}\text { Strongly disagree-Disagree- } \\
\text { Neutral-Agree-Strongly agree }\end{array}$ \\
\hline 14 & $\begin{array}{l}\text { Quotation and invoicing should be done } \\
\text { systematically. }\end{array}$ & $\begin{array}{l}\text { Strongly disagree-Disagree- } \\
\text { Neutral-Agree-Strongly agree }\end{array}$ \\
\hline 15 & Service details should be well communicated. & $\begin{array}{l}\text { Strongly disagree } \\
\text { Neutral-Agree-Strong }\end{array}$ \\
\hline 16 & $\begin{array}{l}\text { It is important to have a customer-friendly } \\
\text { attitude. }\end{array}$ & $\begin{array}{l}\text { Strongly disagree-Disagree- } \\
\text { Neutral-Agree-Strongly agree }\end{array}$ \\
\hline 17 & Interpreter recruitment should be done quickly. & $\begin{array}{l}\text { Strongly disagree-Disagree- } \\
\text { Neutral-Agree-Strongly agree } \\
\end{array}$ \\
\hline 18 & The interpreter should run one's own website. & $\begin{array}{lr}\text { Strongly disagree-Di } \\
\text { Neutral-Agree-Strongly a }\end{array}$ \\
\hline 19 & $\begin{array}{l}\text { The interpreter should be engaging in social } \\
\text { media promotion. }\end{array}$ & $\begin{array}{l}\text { Strongly disagree-Disagree- } \\
\text { Neutral-Agree-Strongly agree }\end{array}$ \\
\hline 20 & $\begin{array}{l}\text { The interpreter should interpret the content of the } \\
\text { speech accurately. }\end{array}$ & $\begin{array}{l}\text { Strongly disagree-Disagree- } \\
\text { Neutral-Agree-Strongly agree }\end{array}$ \\
\hline 21 & The interpreter should interpret fluently. & $\begin{array}{l}\text { Strongly disagree-Disagree- } \\
\text { Neutral-Agree-Strongly agree } \\
\end{array}$ \\
\hline 22 & $\begin{array}{l}\text { The interpreter should interpret terminologies } \\
\text { accurately. }\end{array}$ & $\begin{array}{l}\text { Strongly disagree-Disagree- } \\
\text { Neutral-Agree-Strongly agree }\end{array}$ \\
\hline 23 & $\begin{array}{l}\text { The interpreter should interpret using accurate } \\
\text { grammar. }\end{array}$ & $\begin{array}{l}\text { Strongly disagree-Disagree- } \\
\text { Neutral-Agree-Strongly agree }\end{array}$ \\
\hline 24 & $\begin{array}{l}\text { The interpreter should interpret with good } \\
\text { pronunciation. }\end{array}$ & $\begin{array}{l}\text { Strongly disagree-Disagree- } \\
\text { Neutral-Agree-Strongly agree }\end{array}$ \\
\hline 25 & $\begin{array}{l}\text { The interpreter should interpret the utterances } \\
\text { completely. }\end{array}$ & $\begin{array}{l}\text { Strongly disagree-Disagree- } \\
\text { Neutral-Agree-Strongly agree }\end{array}$ \\
\hline
\end{tabular}

26. Check all the age groups of interpreters you prefer for simultaneous interpreting services.

1) $20-29$

2) $30-39$

3) $40-49$

4) $50-59$

5) No age preference (Age doesn't matter)

B. Consecutive interpreting

If your work requires a consecutive interpreting service, how important do you think the following items would be? Check how strongly you agree to each of the following statements.

* Consecutive interpreting refers to a mode of interpreting where the speaker and the interpreter take turns to speak. For example, the speaker makes utterances for a while and then stops. The interpreter immediately begins to interpret what the speaker has said. 


\begin{tabular}{|c|c|c|}
\hline No. & Items & \\
\hline 1 & $\begin{array}{l}\text { The interpreter should have a master's degree in } \\
\text { Interpreting. }\end{array}$ & $\begin{array}{l}\text { Strongly disagree-Disagree- } \\
\text { Neutral-Agree-Strongly agree }\end{array}$ \\
\hline 2 & $\begin{array}{l}\text { The interpreter should have a certificate in } \\
\text { professional interpreting that ensures one's } \\
\text { interpreting competency. }\end{array}$ & $\begin{array}{l}\text { Strongly disagree-Disagree- } \\
\text { Neutral-Agree-Strongly agree }\end{array}$ \\
\hline 3 & $\begin{array}{l}\text { The interpreter should have a lot of general } \\
\text { interpreting experience. }\end{array}$ & $\begin{array}{l}\text { Strongly disagree-Disagree- } \\
\text { Neutral-Agree-Strongly agree }\end{array}$ \\
\hline 4 & $\begin{array}{l}\text { The interpreter should have a lot of domain- } \\
\text { specific interpreting experience. }\end{array}$ & $\begin{array}{l}\text { Strongly disagree-Disagree- } \\
\text { Neutral-Agree-Strongly agree }\end{array}$ \\
\hline 5 & $\begin{array}{l}\text { The interpreter should have a lot of interpreting } \\
\text { experience specific to my organization. }\end{array}$ & $\begin{array}{l}\text { Strongly disagree-Disagree- } \\
\text { Neutral-Agree-Strongly agree }\end{array}$ \\
\hline 6 & $\begin{array}{l}\text { The interpreter should have a lot of interpreting } \\
\text { experience in high-profile events. }\end{array}$ & $\begin{array}{l}\text { Strongly disagree-Disagree- } \\
\text { Neutral-Agree-Strongly agree }\end{array}$ \\
\hline 7 & $\begin{array}{l}\text { The interpreter should be someone } \\
\text { recommended from my personal sources. }\end{array}$ & $\begin{array}{l}\text { Strongly disagree-Disagree- } \\
\text { Neutral-Agree-Strongly agree }\end{array}$ \\
\hline 8 & $\begin{array}{l}\text { The interpreter should be someone } \\
\text { recommended by commercial interpreting } \\
\text { agencies, headhunters, or PCOs. }\end{array}$ & $\begin{array}{l}\text { Strongly disagree-Disagree- } \\
\text { Neutral-Agree-Strongly agree }\end{array}$ \\
\hline 9 & $\begin{array}{l}\text { The interpreter should have good attitudes and } \\
\text { social skills. }\end{array}$ & $\begin{array}{l}\text { Strongly disagree-Disagree- } \\
\text { Neutral-Agree-Strongly agree }\end{array}$ \\
\hline 10 & The interpreter should have a sense of ethics. & $\begin{array}{ll}\text { Strongly } & \text { disagree-Disagree- } \\
\text { Neutral-Agree-Strongly agree }\end{array}$ \\
\hline 11 & The interpreter should have good appearance. & $\begin{array}{l}\text { Strongly disagree-Disagree- } \\
\text { Neutral-Agree-Strongly agree }\end{array}$ \\
\hline 12 & The interpreter should be a celebrity interpreter. & $\begin{array}{l}\text { Strongly disagree-Disagree- } \\
\text { Neutral-Agree-Strongly agree }\end{array}$ \\
\hline 13 & $\begin{array}{l}\text { Responses to inquiries related to interpreting } \\
\text { services should be done speedily. }\end{array}$ & $\begin{array}{l}\text { Strongly disagree-Disagree- } \\
\text { Neutral-Agree-Strongly agree }\end{array}$ \\
\hline 14 & $\begin{array}{l}\text { Quotation and invoicing should be done } \\
\text { systematically. }\end{array}$ & $\begin{array}{l}\text { Strongly disagree-Disagree- } \\
\text { Neutral-Agree-Strongly agree }\end{array}$ \\
\hline 15 & Service details should be well communicated. & $\begin{array}{l}\text { Strongly disagree-Disagree- } \\
\text { Neutral-Agree-Strongly agree }\end{array}$ \\
\hline 16 & $\begin{array}{l}\text { It is important to have a customer-friendly } \\
\text { attitude. }\end{array}$ & $\begin{array}{l}\text { Strongly disagree-Disagree- } \\
\text { Neutral-Agree-Strongly agree }\end{array}$ \\
\hline 17 & Interpreter recruitment should be done quickly. & $\begin{array}{l}\text { Strongly disagree-Disagree- } \\
\text { Neutral-Agree-Strongly agree }\end{array}$ \\
\hline 18 & The interpreter should run one's own website. & $\begin{array}{l}\text { Strongly disagree-Disagree- } \\
\text { Neutral-Agree-Strongly agree }\end{array}$ \\
\hline 19 & $\begin{array}{l}\text { The interpreter should be engaging in social } \\
\text { media promotion. }\end{array}$ & $\begin{array}{l}\text { Strongly disagree-Disagree- } \\
\text { Neutral-Agree-Strongly agree }\end{array}$ \\
\hline 20 & $\begin{array}{l}\text { The interpreter should interpret the content of } \\
\text { the speech accurately. }\end{array}$ & $\begin{array}{l}\text { Strongly disagree-Disagree- } \\
\text { Neutral-Agree-Strongly agree }\end{array}$ \\
\hline 21 & The interpreter should interpret fluently. & $\begin{array}{l}\text { Strongly disagree-Disagree- } \\
\text { Neutral-Agree-Strongly agree }\end{array}$ \\
\hline 22 & $\begin{array}{l}\text { The interpreter should interpret terminologies } \\
\text { accurately. }\end{array}$ & $\begin{array}{l}\text { Strongly disagree-Disagree- } \\
\text { Neutral-Agree-Strongly agree }\end{array}$ \\
\hline 23 & $\begin{array}{l}\text { The interpreter should interpret using accurate } \\
\text { grammar. }\end{array}$ & $\begin{array}{l}\text { Strongly disagree-Disagree- } \\
\text { Neutral-Agree-Strongly agree }\end{array}$ \\
\hline 24 & $\begin{array}{l}\text { The interpreter should interpret with good } \\
\text { pronunciation. }\end{array}$ & $\begin{array}{l}\text { Strongly disagree-Disagree- } \\
\text { Neutral-Agree-Strongly agree }\end{array}$ \\
\hline 25 & $\begin{array}{l}\text { The interpreter should interpret the utterances } \\
\text { completely. }\end{array}$ & $\begin{array}{l}\text { Strongly disagree-Disagree- } \\
\text { Neutral-Agree-Strongly agree }\end{array}$ \\
\hline
\end{tabular}

26. Check all the age groups of interpreters you prefer for consecutive interpreting services.

1) $20-29$

2) $30-39$

3) $40-49$

4) $50-59$

5) No age preference (Age doesn't matter) 
27. How much are you willing to pay for a professional simultaneous interpreting service? Use the slider scale to indicate the interpreting rate. The standard rate in South Korea is $900,000 \mathrm{KRW}$ per day (up to 6 hours), as indicated in the websites of most of the key graduate schools of interpreting in South Korea.

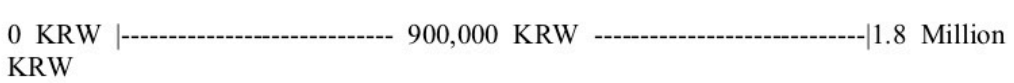

28. How much are you willing to pay for a professional consecutive interpreting service? Use the slider scale to indicate the interpreting rate. The standard rate in South Korea is $900,000 \mathrm{KRW}$ per day (up to 6 hours), as indicated in the websites of most of the key graduate schools of interpreting in South Korea.

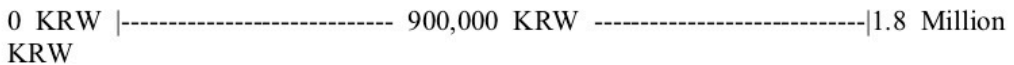

29. Which of the following events do you think require(s) interpreting provided by a professional interpreter? Select all items that match your opinion regardless of the interpreting mode (simultaneous/consecutive).

1) International conferences, Seminars 8 8) Academic conferences

2) Business meetings with external 9) Training, Workshops

partners 10) Press conferences, Press interviews

3) Internal business meetings 11) Conference calls, Video conferences

4) Executive meetings

5) IR (Investor relations)

12) Escort interpreting

6) Negotiations

7) Field trip

13) Courtesy visits

14) Luncheon, Gala dinner

15) Others (Please specify:

30. Which of the following statements best describes your thoughts on interpreting certification system for evaluating and accrediting interpreters' competence?

1) We need interpreting certifications issued by commercial organizations. ( $\rightarrow$ Go to Question 31-a)

2) We need an interpreting certification issued by a representative interpreter organization. ( $\rightarrow$ Go to Question 31-a)

3) We need domain-specific interpreting certifications issued by relevant government agencies or public agencies. ( $\rightarrow$ Go to Question 31-a)

4) We need a national certification. ( $\rightarrow$ Go to Question $31-\mathrm{a}$ )

5) We don't need any interpreting certifications. ( $\rightarrow$ Go to Question $31-b)$

31-a. Why do you think a certification system is necessary? Select all statements that match your opinion

1) It provides a basis for building confidence in an interpreter's competence.

2) Other credentials, such as a master's degree in interpreting or interpreting experience, are not enough to prove one's interpreting competence.

3) Incompetent interpreters can be filtered out.

4) Others (Please specify:

)

31-b. Why do you think a certification system is not necessary?

1) I cannot place trust in the validity of any interpreting certification systems.

2) A master's degree in interpreting is enough to prove one's interpreting competence.

3) A certification system would not gain traction unless all interpreters joined the system.

4) Others (Please specify: )

32. If you have any other thoughts on interpreting, please comment below.

- End of Survey - 